Bond University ePublications@bond

Sports Law eJournal

Faculty of Law

6-20-2014

\title{
Is there an estoppel issue in the Cronulla Sharks and Essendon Bombers doping scandal?
}

David Thorpe

University of Technology, Sydney

Follow this and additional works at: http://epublications.bond.edu.au/slej

Part of the Entertainment, Arts, and Sports Law Commons

\section{Recommended Citation}

David Thorpe. (2014) "Is there an estoppel issue in the Cronulla Sharks and Essendon Bombers doping scandal?" , .

http://epublications.bond.edu.au/slej/19 


\title{
Is there an estoppel issue in the Cronulla Sharks and Essendon Bombers doping scandal?
}

\begin{abstract}
This paper considers the application of the doctrine of estoppel to 'shield' from contract-based prosecution those players of the Cronulla Sharks and Essendon Bombers implicated in recent accusations of doping. The arguably different application of estoppel as between the clubs (which are contractually entitled to punish players for doping) on one hand, and the organising bodies of the National Rugby League (NRL) and the Australian football League (AFL), on the other, is also considered.

\section{Keywords}

Rugby league, AFL, NRL, Essendon Bombers, Cronulla Sharks, doctrine of estoppel, estoppel, anti-doping code, WADC
\end{abstract}

\author{
Disciplines \\ Entertainment, Arts, and Sports Law
}




\title{
IS THERE AN ESTOPPEL ISSUE IN THE CRONULLA SHARKS AND ESSENDON BOMBERS DOPING SCANDAL?
}

\author{
DAVID THORPE*
}

This article considers the application of the doctrine of estoppel to 'shield' from contract-based prosecution those players of the Cronulla Sharks and Essendon Bombers implicated in recent accusations of doping. The arguably different application of estoppel as between the clubs (which are contractually entitled to punish players for doping) on one hand, and the organising bodies of the National Rugby League (NRL) and the Australian football League (AFL), on the other, is also considered.

\section{INTRODUCTION}

This article proposes that a club, in particular the Cronulla or the Essendon clubs, may be estopped from denying responsibility for the use by their athletes of banned performance enhancing substances where these substances were supplied by officials, to use a broad term, employed or appointed by their club and where the athletes concerned had no knowledge that such substances were banned under the World Anti-Doping Code (WADC). ${ }^{1}$ The argument presented here may well extend to others, such as a coach, who in good faith and upon the advice of, say, an 'official' engaged by a club, condoned or encouraged the use of banned substances. ${ }^{2}$

Senior Lecturer in Law, University of Technology Sydney

Some clubs indicated the possibility of imposing internal penalties or advised players to plead guilty to access a reduced penalty: 'Cronulla released a statement on Wednesday evening, outlining the club had been "very proactive in fully cooperating with ASADA and taking other measures that prioritise the integrity of our club and the welfare of our playing group". ... A lawyer hired by Cronulla to deal with the ASADA investigation into possible use of performance-enhancing drugs, has reportedly told some players there is an option to admit use and face a six-month ban or face a two-year ban if eventually found to have used them.': www.anb.net.au/news 7 March 2013; 'Sharks players have reportedly been told they could accept a six-month ban if they had used a banned drug - wittingly or otherwise - or face the maximum twoyear suspension if later found guilty of doing so by ASADA's investigation.': 'Sharks players warned to come forward', ABC News, 7 March 2013.

2 For example, a coach who was informed by a club's 'official' or medico that a particular substance was of value to players and was permitted under the WADC, may argue that the club is estopped from imposing penalties where that coach, due to the information supplied by the official, encouraged players to use a substance later found to be illicit. To illustrate, the 2013 Essendon coach, James Hird, was suspended from coaching 'for bringing the game into disrepute' following his suggested involvement in doping program at the club (see <http://www.essendonfc.com.au/news/2013-08-27/full-list-of-sanctions>). It would seem from some reports that Hird had based any encouragement of players to use supplements on the advice of officials appointed by the club: 'Hird is believed not to have played a role in overseeing the treatment regime.': Crawford C, 'Essendon report widens with four more drugs probed', Herald Sun, July 5, 2013. Indeed, a hearing of the AFL on 27 August 2013 found that this was in fact the case: 'James Hird did not set out to implement a supplements program that would result in players being administered WADA prohibited or harmful substances'; http://www.essendonfc.com.au/news/2013-08-27/full-list-of-sanctions. It can also be noted that Cronulla coach, Shane Flanagan, was stood down for 12 months by the NRL, and Head of Strength and Conditioning, Trent Elkin, had his registration cancelled, as they were 'responsible for a number of the failings that led to those breaches.'; 'Decision on Sharks, Flanagan and Elkin', 5 March, 2014, NRL website: < https://www.nrl.com/decision-on-sharks,-flanagan-andelkin/tabid/10874/newsid/76586/default.aspx > 
An estoppel which prevents a club from enforcing its anti-doping code does not of itself prevent the parent bodies of the NRL or AFL, as institutions distinct from the clubs playing in their competitions, from penalising a player under its own contractual regimen. There is a question, however, given the

close and cooperative relationship between the club and sporting organisation, ${ }^{3}$ whether such a course of action is morally, and perhaps legally, tenable should a court of law find that responsibility rests ultimately with the clubs. In these circumstances, the NRL and AFL will be placed in the invidious position of seeking to punish a player who was exonerated from liability due to the role of his club in distributing, albeit unintentionally, banned substances. It can be noted that the NRL fined the Cronulla Sharks, as a club, $\$ 1 \mathrm{~m}$ because 'preliminary findings have identified serious failures on the part of the Club and certain individuals who had a responsibility to safeguard the health and welfare of its players'. ${ }^{4}$ The influence, or indeed the moral suasion, of the exoneration of a player by a court of law should not be underestimated when matters are brought before the relevant domestic tribunal of a sport or, more broadly, the impact of a judicial finding on public opinion.

Unlike 'Olympic' cases such as Raguz v Sullivan, where it was ruled that the jurisdiction of Australian courts was excluded through the operation of international treaty, there are no apparent contractual arrangements between the AFL or NRL and their players, mandating the Court of Arbitration for Sport (CAS) as the final arbiter of a doping dispute. ${ }^{5}$

3 In Bulldogs Rugby League Club Ltd v Williams [2008] NSWSC 822, Austin J granted leave to the NRL, although not a party to the contract between the player and the club, to separate representation at an interlocutory hearing of the basis that the NRL 'has a substantial commercial interest in the enforcement of the contract.': at [10]. The NRL Player Contract also provides for a level of mutual cooperation among the parties and, moreover, includes a number of provisions that modify, in favour of the NRL, the absolute right of the club and the player to enforce certain terms. For example, although contracting with the club as his employer, Section 3.1 (e) requires a player to 'undergo drug testing if and when requested to do so by the Club, the $N R L$ or the ARL' [emphasis added]; Section $3.1(\mathrm{t})$ requires that a player who wishes to participate 'in any football match of any [other] code' will not do so 'without the prior written consent of the Club, which the Player acknowledges will only be given with the consent of the NRL'. To further illustrate, in describing the creation of present the ARL Commission from the old NRL Partnership, the NRL website states, 'each of the NRL Partners stood aside to support a new organisation born out of a sense of opportunity and common purpose.': <http://www.nrl.com/About/ARLCommission/tabid/10891/Default.aspx >. Indeed, it is not unusual for a parent organisation to 'suggest' a particular mode of action to a club in respect to disciplining players, or for a club to seek 'approval' from the parent organisation. For example, when the St Kilda AFL club cancelled the contract of Jason Gram for misbehaviour, 'St Kilda said it informed the AFL of its move and the league supported the decision.' Lalor P and Walsh C, 'St Kilda tears up Jason Gram's contract', The Australian, 31 October 2012.

4 Sharks fined \$1m, Flanagan suspended', 17 December 2013, NRL website: < http://www.nrl.com/sharksfined-1m,-flanagan-suspended/tabid/10871/newsid/75768/default.aspx >

5 Raguz $v$ Sullivan [2000] NSWCA 240. Before the CAS, Sullivan was successful over Raguz in claiming selection to the judoka team for the Sydney Olympics. Sullivan claimed she was not a party to the contract granting CAS exclusive jurisdiction. The NSWCA, drawing upon the New York Convention on the Recognition and Enforcement of Foreign Arbitral Awards, found that as the case did not involve a 'domestic arbitration agreement' but rather 'arbitration in a country other than Australia' [at 109] jurisdiction was ceded to CAS [Article R59 of the Code of Sports Related Arbitration]. That is, the 'seat' of the CAS is Lausanne, Switzerland. Although the NSW Court's jurisdiction could not be excluded in respect to a domestic arbitration where the arbitration is not domestic jurisdiction may be denied [Commercial Arbitration Act (NSW) Section 40 (6)(7)]. See comments: Prof G Kaufmann-Kohler (President of the Ad Hoc Division of CAS) 'Identifying and Applying the Law Governing the Arbitration Procedure - The Role of the Law of the Place of Arbitration', International Council for Commercial Arbitration, Congress Series no. 9 Paris 1998, 336 at 348, (footnotes omitted): 'Wherever a CAS arbitration takes place physically, it always has its legal place or seat in Lausanne. This applies to all CAS arbitrations, wherever the hearings take place, whether they are managed by the Lausanne office exclusively or in conjunction with a decentralized office, and it includes arbitrations handled on the site of the Olympic Games.' 
This paper also suggests that estoppel is relevant where athletes, and relevant others, are to be prosecuted for the contractual wrong of 'bringing the game into disrepute'; an alternate approach suggested as a means to punish players involved in illicit 'peptide' or 'supplement' doping.

This article will review the doctrine of estoppel and the adoption of estoppel by the CAS. To illustrate the application of estoppel to doping, the case of tennis player Bohdan Ulihrach will be reviewed in some depth. Ulihrach was exonerated from liability for doping when the parent body, the Association of Tennis Professionals (ATP), was estopped from prosecuting the player after it was discovered that its employee trainers had supplied him with a supplement contaminated with Nandrolone.

\section{THE FACTUAL BACKGROUND}

In February 2013, members of the then Federal Labor Government, Sports Minister Kate Lundy and Justice Minister Jason Clare, ${ }^{6}$ announced in a media release that Australian athletes were involved in the systematic use of banned performance enhancing substances, in particular 'peptides', a protein that assists in muscle growth and injury recovery. ${ }^{7}$ Mr Clare said, 'Multiple athletes from a number of clubs in major Australian sporting codes are suspected of currently using or having previously used peptides, potentially constituting anti-doping rule violations.' The media release stated further that, 'some coaches, sports scientists and support staff of elite athletes have orchestrated and/or condoned the use of prohibited substances.' Within a short time suspicion focused on players' of the NRL's Cronulla Sharks and the AFL's Essendon Bombers and a 'sports scientist' associated with these clubs, Stephen Dank, who was described as 'the investigation's central figure'. ${ }^{8}$ Dr Dank (PhD) has denied he administered any supplements banned under the WADC. ${ }^{9}$

A later independent report into Cronulla's supplement program detailed 'how a number of Cronulla players were "administered" with peptides ... between March and May in 2011.'10 The defence of players and others to the accusations of doping has been, by and large, to deny the offence. ${ }^{11}$

President of WADA, John Fahey, said, 'If you are caught, you will be dealt with in a manner that can take you out of the sport forever'. ${ }^{12}$ Richard Ings, former Australian Sports Anti-Doping Authority

6 Joint media release, The Hon Jason Clare MP and Senator The Hon Kate Lundy, 7 February 2013:

$<$ http://www.katelundy.com.au/2013/02/07/organised-crime-and-drugs-in-sport/>

7 Growth hormone releasing peptides are a Schedule 2 substance under the 2013 Prohibited List of the WADA Code. This Schedule includes not merely listed substances but 'other substances with similar chemical structure or similar biological effect(s)'. Peptide hormones in respect to the AFL/NRL

investigations were listed in the media as CJC01295 and GHRP-6. Other substances mentioned by the media include the anti-obesity drug AOD-9604, Beta 4 CJC-1295 and calf's blood.

8 Massoud J, ASADA interviews finish with Cronulla Sharks skipper Paul Gallen, The Daily Telegraph, 23 August 2013.

$9 \quad$ Replying to a question on the 'The7:30 Report', Dr Dank (PhD) said that the players at Essendon were given 'intravenous injections of vitamin B and vitamin C which are quite compliant with the WADA Code.' In respect to peptide use Dr Dank (PhD) stated, 'all very, very legal and certainly all within the constraints of WADA.' Meldrum-Hanna, C, 'Former Essendon sports scientist describes AFL supplement culture': The 7:30 Report, 11 February 2013, Australian Broadcasting Corporation. < http://www.abc.net.au/7.30/content/2013/s3688014.htm > Refer also to claims by Dank that he had been defamed by imputation in a number of media reports: Dank v Whittaker (No1) [2013] NSWSC 1062; Dank v Cronulla-Sutherland District Rugby League Football Club [2013] NSWSC 1101; Dank v Whittaker (No 2) [2013] NSWSC 1064; Dank v Carroll, Dank v Nationwide News Pty Ltd [2013] NSWSC 1122.

10 Massoud J, Hooper J and Wilson R, 'Peptides given to Cronulla Sharks players may have hastened former player Jon Mannah's death', The Daily Telegraph, 26 April 2013.

11 Indeed, some commentators have suggested supplements supplied at Essendon were not illicit under the WADC. See, for example, Hardie M, 'ASADA, the AFL and WADA - the main game', $<$ http://communities.deakin.edu.au/deakin-speaking/node/608> 16 March 2014.

12 Le Grand C, 'Big sport lays down the law with four-year bans for drug cheats', The Australian, 8 February 2013. 
(ASADA) chief executive, stated that 'ignorance is no defence amid speculation Sharks players could sue the club if suspended ...13 Months later the question of prosecution remained open, Ings commenting that it is not a question of 'if' infraction notices will be issued against players, 'it's a question of when and how many.14 In November 2013 John Fahey continued to reflect on the likelihood of prosecution by ASADA, stating, 'we've still got a few chapters to be read on this before it's finished'. ${ }^{15}$ As late as March 2014, the issue continued as a matter of interest when James Hird's wife stated that her husband, 'didn't plead to any breach of the player rules, he wasn't found guilty of any breach of the player rules. In the end, it was the threats and the bullying of the AFL to the club and to himself'. ${ }^{16}$

\section{THE BASIS IN CONTRACT}

The 'NRL Player Contract' is a standard form contract supplied to each club by the NRL and bearing the NRL logo. The primary contractual relationship is between the player and the club: 'The relationship between the Player and the Club, as evidenced by this Agreement, is one of employee and employer, for the purposes of participating in the NRL Competition ... Representative Competitions ... and Related Competitions..$^{17}$ The signatories to the NRL contract are the player, the club representative and the player's agent.

The contractual capacity of the NRL to penalise players for doping and other offences, is established through the 'NRL Player Registration Application'; the document by which the player is registered as a 'Player in the NRL Competition'. By registration the player agrees to abide by various 'schedules' attached to the player contract including the 'NRL Code of Conduct' and the 'NRL Anti-Doping Rules'. ${ }^{18}$

Under Section 8.1(b) of the NRL Contract, 'Termination for Breach', the player is instructed to 'not engage in misconduct or otherwise act in a manner inconsistent with the best interests, image or welfare of the NRL, the NRL Competition ... the Club or other Clubs of the Game.' Section 8.2 (j) states that a player 'must not ... commit any Doping Offence'.

In addition to the sanctioning powers granted to the NRL through the Anti-Doping Rules, the Player Contract permits the Board of a club to punish their players who engage in doping offences or in conduct that 'might bring into disrepute' the club or the game. ${ }^{19}$ Section $8.5(\mathrm{~b}-\mathrm{e})$, 'Action by the $\mathrm{Club}^{\prime}$ ', permits the Board of a club to 'caution or reprimand the Player ... fine the Player ... suspend the player for a period not exceeding 18 rounds ... or terminate this Agreement with immediate effect.'

13 <www.anb.net.au/news> 7 March 2013.

$14 \quad$ Masters R, 'Where are the charges?' Sydney Morning Herald, 14 October 2013.

15 <http:/www.news.com.au/sport/afl/wada-chief-john-fahey-says-essendon-still-under-investigation-fromantidoping-agencies/story-fnelctok-1226756764403>

16 Milligan L, “"James Hird was a scapegoat” for the AFL claims wife', The 7:30 Report, 20 March, 2014, Australian Broadcasting Corporation. <http://www.abc.net.au/7.30/content/2014/s3968301.htm>

Reference is to Tania Hird.

$17 \quad$ NRL Playing Contract (2012-2013).

18 NRL Player Registration Application (2012-2013). Section 2 of the application states: 'In signing this Application for registration, and in return for the NRL agreeing to consider my application for registration as a Player in the NRL Competition ... I agree: (a) To comply with, and be bound by, the NRL Rules including (i) Schedule One - NRL Code of Conduct; (ii) Schedule Two - NRL Anti-Doping Rules.' Furthermore, Section 2 (c) states that the player agrees 'To submit to the jurisdiction of, and comply with any decisions or determinations made by, the Board, The Chief Executive office ... the Anti-Doping Tribunal.'

19 NRL Playing Contract (2012-2013). The 'Board' 'means the board of directors of the Club': Section 29 Definitions and Interpretations'. 
AFL players also 'agree to comply with the Anti-Doping Code as part of the Standard Playing Contract.' ${ }^{20}$ The AFL and NRL Anti-Doping Codes, being compliant with the ASADA and WADA dictates, are materially identical. Under the AFL Anti-Doping Code,21 doping is prohibited through section 11.1:

(a) sufficient proof of an Anti-Doping Rule Violation ... is established by either of the following: presence of a prohibited Substance or its metabolites or Markers in the Player's A Sample where a Player waives analysis of the B Sample and the B Sample is not analysed; or where the Player's B Sample is analysed and the analysis of the Player's B Sample confirms the presence of the Prohibited Substance or its Metabolites or Markers found in the Player's A Sample.

And under section 11.2:

(a) It is each Player's personal duty to ensure that no Prohibited Substance enters his body. Accordingly, it is not necessary that intent, fault, negligence or knowing use on the Player's part be demonstrated in order to establish an Anti-Doping Rule Violation or Use of a Prohibited Substance of Prohibited Method.

The use, attempted use, or possession of prohibited substances and prohibited methods incurs a penalty or two years ineligibility to play. ${ }^{22}$ A second offence, depending on ameliorating or aggravating factors, may or may not result in a life time ban from the sport. ${ }^{23} \mathrm{~A}$ third offence 'will always result in a lifetime period of ineligibility'. ${ }^{24}$

Clearly it is a player's responsibility to prevent prohibited substances from entering his or her body and to avoid engaging in other forms of doping offence. Nonetheless, in common with most antidoping schemes a player who can show 'no fault or negligence' will have his or her period of ineligibility eliminated, ${ }^{25}$ or where 'no significant fault or negligence' can be shown the period of ineligibility may be reduced by as much as one half of the minimum period of ineligibility. ${ }^{26}$

Under the ASADA Act and the National Anti-Doping Scheme, ASADA possesses the legislative authority to investigate violations of the anti-doping rules of the ASADA Act, to make findings in respect to these investigations, to notify players, officials and parent sporting organisations, and 'to present its findings and recommendations as to consequences at hearings of the AFL Tribunal, the AFL Appeals Board or CAS, either at the AFL's request or on its own initiative. ${ }^{27}$

\section{THE DOCTRINE OF ESTOPPEL}

The general nature of estoppel was explained by Lord Cranworth in West $v$ Jones:

Where a party has by words or conduct, made a representation to another leading him to believe in the existence of a particular fact or state of facts, and that other person has acted on the faith of such representation, then the party who made the representation shall not afterwards be heard to say that the facts were not as he represented them to be. ${ }^{28}$

The purpose of the doctrine of estoppel, according to Parkinson, 'is to preclude the unconscientious departure by a party from an assumption for which he or she bears some responsibility, and which

\footnotetext{
20 AFL Players Association: <http://www.aflpa.com.au/behind_the_scenes/rules_and_regulations/>

21 National Anti-Doping Code, AFL, June 2013, section 4.1. Additional forms of the offence are found in this section.

$22 \quad$ National Anti-Doping Code, AFL, June 2013, section 14.1.

23 National Anti-Doping Code, AFL, June 2013, section 14.6 (a).

24 National Anti-Doping Code, AFL, June 2013, section 14.6 (c).

$25 \quad$ National Anti-Doping Code, AFL, June 2013, section 14.4 (a).

26 National Anti-Doping Code, AFL, June 2013, section 14.4(b).

27 National Anti-Doping Code, AFL, June 2013, section 4.1.

$28 \quad$ West $v$ Jones (1851) 1 Sim (NS) 205 at 207; 61 ER 79 at 81.
} 
has been adopted by another party as the basis of a course of conduct, an act or omission which would operate to that other party's detriment if the assumption were not adhered to'.$^{29}$

In Thompson v Palmer Dixon J, in a statement recognised as encompassing both common law and equitable estoppel,,$^{30}$ explained the object of the doctrine of estoppel was:

\begin{abstract}
to prevent an unjust departure by one person from an assumption adopted by another as the basis of some act or omission which, unless the assumption is adhered to, would operate to that other's detriment. ... He may be required to abide by the assumption because it formed the conventional basis upon which the parties entered into contractual or other relations ....; or because knowing the mistake the other laboured under, her refrained from correcting him when it was his duty to do so; or because of his imprudence, where care was required of him, was a proximate cause of the other party's adopting and acting upon the faith of the assumption; or because he directly made assumptions upon which the other party founded the assumption. ${ }^{31}$
\end{abstract}

In general terms, the foundation in fact of the suggested estoppel is that representations made by 'sports scientists' appointed by the clubs, or by the clubs themselves, led players to assume that supplements with which they were supplied complied with the WADC and, in consequence, these players suffered detriment after consuming banned substances they would not otherwise have consumed. This general foundation is refined in the proposed applications below. For the purposes of the present discussion, where a club is estopped from denying its responsibility for instances of doping, a parent sporting organisation which nonetheless seeks to pursue doping violations against a player who, without notice, took banned substances on the advice of club officials, will be placed in the ignominious position of contradicting, and indeed placing itself above, the findings of a court of law.

From the perspective of a club, or perhaps the parent organisation, a claim in estoppel is resisted by asserting that the elements of estoppel are not made out, in particular whether the plaintiff adopted the assumption, absence of knowledge by the defendant that the plaintiff relied on the assumption, and whether in fact the plaintiff suffered any detriment. ${ }^{32}$

Three forms of estoppel are considered below; two of which fall within the category of estoppel in pais:

\title{
1. Estoppel in pais (conduct)
}

Estoppel in pais, which includes both common law estoppel and promissory estoppel in equity, ${ }^{33}$ is concerned with the conduct of the party to be estopped. Deane J stated that the central principle of estoppel by conduct centres on the proposition 'that the law will not permit an unconscionable ... departure by one party from the subject matter of an assumption which has been adopted by the other party as the basis of some relationship, course of conduct, act or omission which would operate to the other party's detriment if the assumption be not adhered to for the purposes of the litigation' ${ }^{34}$

29 Parkinson P (ed), The Principles of Equity,( LBC, Sydney, (2003) 2 $2^{\text {nd }}$ ed.) [701]. Quoted with approval in Young P, Croft C and Smith M, On Equity, (Lawbook, Australia, 2009) 798. (Hon Justice Young, Judge of Appeal, SCNSW).

30 See Parkinson P (ed), The Principles of Equity, (LBC, Sydney, (2003) $2^{\text {nd }}$ ed). [715].

31 Thompson v Palmer (1933) 49 CLR 507, 547.

32 See, for example, Ryledar Pty Ltd v Euphoric Pty Ltd [2007] NSWCA at [200].

33 Young et al note that 'the authorities indicate that the expression is not necessarily used consistently and may be employed both in a broad sense, which includes promissory estoppel in equity, and a narrow sense, where it is limited to common law estoppel. Young P, Croft C and Smith M, On Equity, (Lawbook, Australia, 2009) 806. Estoppel in equity is considered below.

$34 \quad$ Commonwealth $v$ Verwayan (1990) 170 CLR 394 at 444. 
Importantly for those players concerned, a representation need not involve the use of words. As Mason and Deane JJ explained in Legione $v$ Hateley, 'conduct' alone may be sufficient to ground an estoppel, provided it is clear and unequivocal:

The requirement that a representation as to existing fact or future conduct must be clear if it is to found an estoppel in pais or a promissory estoppel does not mean the representation must be express. Such a clear representation may properly be seen as implied by the words used or to be adduced from either failure to speak where there was a duty to speak or from conduct. Nor is it necessary that a representation be clear in its entirety. It will suffice if so much of the representation as is necessary to found the propounded estoppel satisfies the requirement. ${ }^{35}$

There are two forms of estoppel in pais (conduct) which are relevant to the present discussion: (a) estoppel by representation and (b) estoppel by convention. As indicated in Legione v Hateley, the representation is confined to an existing fact (including a fact as to the state of legal relations between parties) rather than, as may be the case in equitable estoppel, future conduct.36

(a) Estoppel by representation involves a representation made by the party to be estopped that causes another to alter his or her position to his or her detriment. Lord Tomlin in Greenwood v Martins Bank listed the elements necessary to establish an estoppel by representation:

(1) A representation or conduct amounting to a representation intended to induce a course of conduct on the part of the person to whom the representation is made. (2) An act of omission resulting from the representation, whether actual or by conduct, by the person to whom the representation is made. (3) Detriment to such a person as a consequence of the act or omission. ${ }^{37}$

In terms of the present discussion, a player will claim that the club through its 'official' or 'sports scientist' represented, by words or conduct, that the supplements with which he was supplied were free of banned substances. Indeed, that the advising sports scientist had been properly vetted for both expertise and ethics through the process of procurement. On the strength of the representation the player consumed the supplement. In consuming the supplement the player suffered the detriment of disqualification from the game and other penalties.

Where an estoppel is proved, a club will be estopped from departing from the representation that the supplements administered by its officials were free of banned substances.

(b) Estoppel by convention, rather than involving a representation made by one party to another, 'concerns a common participation in an assumed state of affairs'. ${ }^{38}$ As with estoppel by representation, the complaining party must suffer detriment due to the defendant's departure from the subject matter of the assumption: 'estoppel by convention is a form of estoppel founded not on a representation of fact made by a representor and acted on by a representee to his detriment, but on the conduct of relations between the parties on the basis of an agreed state of facts which both will be estopped from denying'. ${ }^{39}$ To emphasise, in holding the common assumption either party may be estopped. ${ }^{40}$ Revisiting the words of Dixon J in Thompson $v$ Palmer, the party to be estopped 'may be required to abide by the assumption because it formed the

$35 \quad$ Legione v Hateley (1983) 152 CLR 406 439-152 CLR 406, 439.

36 Nonetheless, Mason CJ, in Commonwealth $v$ Verwayan (1990) 170 CLR 394 413, took the position that the distinction should be abandoned: '... it should be accepted that there is but one doctrine of estoppel, which provides that a court of common law or equity may do what is required, but not more, to prevent a person who has relied upon an assumption as to a present, past or future state of affairs (including a legal state of affairs) ... from suffering detriment.'

37 Greenwood v Martins Bank Ltd [1933] AC 51, 57 AC 51, 57.

38 Mulholland R, 'Estoppel by Convention' [2002] NZLJ 395 at 397 reported in Dal Pont G and Chalmers D, Equity and Trusts in Australia (2004 $3^{\text {rd }}$ ed) [10.45].

39 Con-Stan Industries of Australia Pty ltd v Norwich Winterthur Insurance (Australia) Ltd (1986) 160 CLR 266 at 244-5.

40 See, for example, Ryledar Pty Ltd v Euphoric Pty Ltd [2007] NSWCA at [200]. 
conventional basis upon which the parties entered into contractual or other mutual relations ...' ${ }^{41}$ Further, 'estoppels by convention may be created ad hoc, expressly, by a course of dealing, or by other acts and declarations.' ${ }^{42}$

Estoppel by convention may apply to the legal, including contractual, relations between parties. In Grundt $v$ Great Boulder Gold Mines Dixon J stated, 'The law should not permit an unjust departure by a party from an assumption of fact which he has caused another to adopt or accept for the purpose of their legal relations'.43

In Moratic Pty Ltd $v$ Gordon, ${ }^{44}$ the plaintiffs claimed that, although a contractual term required them to pay an 'additional rent', as the amount had never been demanded or paid and as both parties assumed payment was not mandated, an estoppel by convention applied to estop the lessor from later claiming the rent in question. Brereton J found that both parties 'conducted their relationship on the basis of that assumption ... Regardless of the terms of the lease ... both parties are therefore estopped from denying the truth of the assumption'. ${ }^{45}$ His Honour declared the plaintiffs were not liable to pay.

The following application is proposed: The parties conducted their legal relations on the commonly assumed basis that where supplements were provided by the club, the anti-doping term would not be asserted against the players, or, on the assumed basis that supplements supplied by those engaged by the clubs were free of banned substances. In the club's departure from the assumption, the player suffered detriment in the form of a penalty.

\section{Equitable (promissory) estoppel}

The rationale underpinning equitable estoppel was given Mason CJ and Wilson J in Waltons Stores (Interstate) Pty Ltd v Maher:

the principle that equity will come to the relief of a plaintiff who has acted to his detriment on the basis of a basic assumption in relation to which the other party to the transaction has "played such a part in the adoption of the assumption that it would be unfair or unjust if he were left free to ignore it. ${ }^{46}$

In Waltons Stores v Maher Brennan J said that, to establish an equitable estoppel,

it is necessary for a plaintiff to prove that (1) the plaintiff assumed that a particular legal relationship then existed between the plaintiff and the defendant or expected that a particular legal relationship would exist between them ... (2) the defendant has induced the plaintiff to adopt that assumption or expectation; (3) the plaintiff acts or abstains from acting in reliance on the assumption or expectation; (4) the defendant knew or intended him to do so; (5) the plaintiff's action or inaction will occasion detriment if the assumption or expectation is not fulfilled; and (6) the defendant ... failed ... to avoid that detriment ... by fulfilling the assumption or expectation or otherwise. $^{47}$

The unconscionability that attracts the equitable jurisdiction is the failure of the defendant to fulfil the assumption or expectation. ${ }^{48}$ As Justice Brereton stated extra-judicially, equitable estoppel relates to an assumption regarding the legal relations between the parties, extending to legal relations in respect

Thompson v Palmer (1933) 49 CLR 507547.

Handley KR, Estoppel by Conduct and Election (Sweet \& Maxwell, London, 2006) [8-001].

Grundt v Great Boulder Pty Gold Mines Ltd (1937) 69 CLR 641, 674-675 per Dixon J.

Moratic Pty Ltd v Gordon [2007] NSWSC 5.

Moratic Pty Ltd v Gordon [2007] NSWSC 5 at [52].

Waltons Stores (Interstate) Ltd v Maher (1988) 164 CLR 387, 404.

Waltons Stores (Interstate) Ltd v Maher (1988) 164 CLR 387, 428-9.

Waltons Stores (Interstate) Ltd v Maher (1988) 164 CLR 387, 423 per Brennan J. 
to a contract: 'In equitable promissory estoppel, it is necessary for a plaintiff to establish ... that it has adopted an assumption as to the terms of a legal relationship with the defendant.' 49

Noting again that conduct may ground a representation as forcefully as words, ${ }^{50}$ players concerned with accusations of doping will claim that in distributing supplements the club must be taken to have represented, or promised, that it would not assert its contractual entitlement to prosecute players where those supplements were found to have contained banned substances. Alternatively a club may be estopped from denying it represented, or promised, that the supplied supplements were free of banned substances.

\section{BRINGING THE SPORT INTO DISREPUTE}

Equally, on the above analysis, a club may be estopped from relying on a 'bring the sport into disrepute' clause to prosecute a player, or indeed a coach or other relevant appointee, where the club, through its 'official', is responsible for the detriment endured by a player who assumed that the substances which were supplied and consumed conformed to the WADC.

\section{THE CASE OF BOHDAN ULIHRACH}

In 2002 ATP tennis player Bohdan Ulihrach of the Czech Republic tested positive to Nandrolone, a Class 1 Prohibited Substance. This substance was apparently internalised when Ulihrach was competing in the Kremlin Cup, Moscow, Russia, in October of that year. Ulihrach was at a loss to explain how the drug entered his system, citing initially the statistical improbability that the A and B samples would vary (as they did), that the positive test was the result of the 'natural production' of his body, before settling on the argument that Russian meat he had eaten was laden with growth hormones. ${ }^{51}$

Under the Association of Tennis Professionals (ATP) doping rules, 'a player is absolutely responsible for any Prohibited Substance found to be present within his body.' The rules applied to Ulihrach through a consent form he signed in 2001. The ATP Anti-Doping Tribunal (the Tribunal) was unconvinced by the arguments of Ulihrach's medically qualified witnesses, Dr Hill and Professor Starka, an endocrinologist, on the biochemical and analytical aspects of the test result. In May 2003 the Tribunal imposed a mandatory two year suspension on Ulihrach, the forfeiting of prize money from the 2002 Kremlin Cup and the expunging of points earned from that tournament.

In June 2003 Ulihrach requested the Chairman of the Tribunal re-open proceedings. He cited a number of reasons: that at a tournament in Palermo in September 2002 'he took electrolyte tablets provided to him by an ATP sports medicine trainer in doses of 3 tablets twice a day for a period of 3 to 4 days. Similarly, during the ATP tournament in Moscow he took approximately 3 electrolyte tablets a day for the period of 2 days'.$^{52}$ He referred to reports in the ATP Players' Weekly which expressed 'ever increasing concerns about quality control and contamination in the manufacturing of health-related products'. ${ }^{53}$

49 The Honourable Justice PLG Brereton, 'Equitable Estoppel in Australia: The Court of Conscience in the Antipodes', Speech to the Australian Law Journal Conference: Celebrating 80 Years, 16 March 2007.

$50 \quad$ Legione $v$ Hateley (1983) 152 CLR 406, 439.

51 Coincidentally Ulihrach was notified of the positive test by Executive Vice-President of Rules and Competition of the APT, Richard Ings, a subsequent head of ASADA and commentator on the AFL/NRL doping controversy, the subject of this paper.

52 Decision of the ATP Tour Anti-Doping Tribunal on the re-opening of the hearing appeal of Bohdan Ulihrach at [3.3].

53 Decision of the ATP Tour Anti-Doping Tribunal on the re-opening of the hearing appeal of Bohdan Ulihrach at [3.4-5]. Ulihrach made direct reference to the contamination of certain supplements by the Australian firm PAN Pharmaceuticals, stating that the Australian Therapeutic Goods Administration had 
The Tribunal was informed in June 2003 by ATP officials that the source on the Nandrolone contamination may have been an electrolyte product provided by ATP trainers at the Palermo and Moscow tournaments. An investigation also revealed that 29 other players had tested positive for Nandrolone and that most of these players had stated they used the electrolyte product 'at or about the time of their drug test.' These tests occurred over the period from August 2002 to May 2003 and in each case the athlete's specimen showed a unique mass spectrometry chromatogram - one consistent with the use by all players of a common substance.

On 23 June the ATP Tour agreed to re-open the Anti-Doping (Appeals) Tribunal in light of the new information bearing on Ulihrach's case. On its own initiative the ATP Tour appointed Richard Young to conduct an investigation and provide a statement of findings to Ulihrach's counsel. The investigation found in part:

During this time [August 2002 to May 2003] ATP trainers were, without the ATP's authorisation, distributing and making available to ATP players (including Mr Ulihrach) various nutritional and mineral supplements.

For the last several years, the ATP has repeatedly warned its player not to take nutritional or mineral supplements because of the inherent danger of contamination.

These products were often dispensed by ATP trainers from open containers which were left unattended in training rooms at tournaments.

One of the products distributed and made available by ATP trainers during this time was an electrolyte tablet [name withheld].

The electrolyte product was distributed by the ATP trainers at all of the tournaments where testing disclosed the presence of Nandrolone metabolites during the time period referred to above.

Specifically Mr Ulihrach used the electrolyte product at the tournament where he tested positive.

The ATP has not been able to definitively establish that contamination of the electrolyte product or other supplements distributed by its trainers was not the source of these positive and near positive tests. ${ }^{54}$

While the ATP admitted some responsibility for the distribution of a banned substance, it is also made clear that players who used products from 'open containers which were left unattended in training rooms' took a risk uncharacteristic of a prudent athlete for which, in normal circumstances, no amelioration in penalty would be available. Nonetheless, the preponderant cause was found to be the actions of the ATP Tour through its trainers.

The Appeals Tribunal determined that, 'there is likely a single source product or a single source substance in different products supplied by the ATP trainers that are contributing to the analytical results. These are the facts. The inferences which ought to be drawn in this case, given the results of the investigation to date, is that the common source of the positive results is a substance the Player was given by the ATP trainers'. ${ }^{55}$

\section{THE ATP, CAS AND EQUITABLE ESTOPPEL}

The Appeals Tribunal was called upon to consider whether the ATP Tour, though the conduct of its trainers, was estopped from asserting its strict legal right to prosecute the player Ulihrach:

found PAN substituted untested ingredients, fabricated test results, did not properly clean machinery and sold products that were $700 \%$ stronger than labelled.

54 Decision of the ATP Tour Anti-Doping Tribunal on the re-opening of the hearing appeal of Bohdan Ulihrach at [5]

55 Decision of the ATP Tour Anti-Doping Tribunal on the re-opening of the hearing appeal of Bohdan Ulihrach at [19]. 
Equitable estoppel is to be applied as a matter of fairness and good conscience to estop the person whose conduct has brought the situation about from asserting their legal rights against another party who may have been misled or affected by that conduct. ... As a matter of good conscience and fairness to the Player before the Tribunal the ATP ought to be estopped from defending the RB finding that there is a Doping Offence in the Player's case as it is otherwise required to do by Rule L 10. Furthermore, that estoppel would preclude the ATP from enforcing its Anti-Doping Rules as set out in its Rulebook.

The estoppel also applies to the principle of strict liability as set out in Rule C \#. The estoppel precludes the ATP from enforcing its Rulebook and in particular ... where it states that "the Player's lack of intent or lack of fault [is not] a defence to a Doping Offence".

The estoppel has this effect because the ATP through its trainers is by inference the likely source of the contaminated product. Therefore, the estoppel precludes the ATP from enforcing its AntiDoping Rule of strict liability. ${ }^{56}$

In coming to its determination, the Appeals Tribunal applied the doctrine of estoppel as recognised under the law of the State of Delaware, ${ }^{57}$ and, in addition, the 'lex sportif of CAS'. In respect to the law of Delaware the Tribunal quoted from Bechtel $v$ Robinson:

Under Delaware law, "equitable estoppel may arise when a party by its conduct intentionally or unintentionally leads another, in reliance upon that conduct, to change position to his detriment" (Wilson $v$ American Ins Co) ... As a result, the person whose conduct has brought the situation about [is] estopped from asserting his legal rights against the party so misled. (Wolf v Globe Liquor Co)...

Equitable estoppel in the modern sense arises from the conduct of a party, using that word in its broadest meaning as including his spoken or written words, his positive acts, and his silence or negative omission to do anything. Its foundation is justice and good conscience. ${ }^{58}$

The plaintiff's 'change of position' is fundamental to estoppel. ${ }^{59}$ In Ulihrach the change of position was, apparently, the ingestion of a banned substance that would not otherwise have been consumed.

Reference was also made to estoppel in the CAS determination of IAAF $v$ USATF, ${ }^{60}$ a matter that concerned the obligation of the USATF under the IAAF rules to disclose the existence of certain 'positive' doping tests and to reveal the basis for determinations of Hearing Panels where athletes had been exonerated of doping offences. The CAS commented, '[The] USATF argues that the doctrine of estoppel "not only applies in these circumstances, it was invented for them." ... Such rhetoric strains, or at least exaggerates, the facts and law with this arbitration is concerned; but it services to make the point, which is that fairness lies very much at the heart of the concept of equitable estoppel.'

\section{STRICT LIABILITY AND THE ‘INADVERTENT’ DOPING CASES}

In a number of well known cases athletes have tested positive for banned substances in circumstances where, due to the intrusion of a third party, their moral culpability was argued to approach zero. Nonetheless, even where the Tribunal expressed regret at imposing a sanction on an athlete, the rules of strict liability did not prevent the imposition of comparatively severe punishments. ${ }^{61}$

56 Decision of the ATP Tour Anti-Doping Tribunal on the re-opening of the hearing appeal of Bohdan Ulihrach at [26-27]. In fairness, the ATP Tour in its submissions to the Appeals Tribunal recognised that it was estopped from applying its rules to prosecute Ulihrach; recorded at page 6 of Appeals Tribunal Decision.

57 Under Rule U 1 of the ATP Anti-Doping Rules, the Anti-Doping program is governed in all respects by the laws of Delaware.

58 Bechtel v Robinson 886 F2d 644, 650 (United States CA, 3 $3^{\text {rd }}$ Circuit, 1989).

59 See, for example, in respect to Australian cases Grundt v Great Boulder Pty Gold Mines Ltd (1937) 69 CLR 641, 675.

60 IAAF $v$ USATF Ordinary Division of the Court of Arbitration for Sport, 10 January 2003 at [132].

61 For an informative review of the issues involved see: Amos A, 'Inadvertent Doping and the WADA Code', (2007) 19.1 Bond Law Review 1. 
In Squizzato v Federation Internationale de Natation Amateur (FINA), a 17 year old swimmer tested positive for an anabolic agent after using a cream to combat a skin infection purchased for her by her mother. Although able to show 'no significant fault or negligence', a ban of one year was imposed on the basis that 'at least she could have asked her doctor, coach or any other competent person to double check the contents of the cream'.62

In Raducan $v I^{O C}{ }^{63}$ a 16 year old Rumanian gymnast who had been supplied Nurofen by her team doctor, tested positive for pseudoephedrine. She claimed because 'she had a relationship of trust' with the doctor she bore no responsibility. The CAS Panel described Raducan as 'a fine, young, elite athlete' but found that the commitment to 'drug-free sport' required that the 'Anti-Doping Code must be enforced without compromise' thereafter disqualifying her from the gold medal.

After participating in the FIS Alpine World Cup Downhill in Canada's Lake Louise, Hans Knauss, an Austrian, tested positive for norandrosterone. ${ }^{64}$ The source of the substance was a nutritional supplement called 'Super Complete Capsules' imported by Ultimate Nutrition. Prior to use Knauss had 'obtained a written certification from Ultimate Nutrition that their products were clean' (Krauss later filed a criminal complaint against the importer). The CAS Panel found the penalty of 18 months suspension proportional to the athlete's wrong.

\section{ESTOPPEL, THE MORAL ARGUMENT, AND THE PARENT SPORTING ORGANISATION}

In the cases cited above the athlete formed the view, on the advice of others, that it was safe to consume the products later found to contain prohibited substances. Despite the obvious fault of a third party, the CAS found the cited athletes liable. Given this fact the question for consideration is why the AFL and NRL players in question should be excused from the application of the strict liability rules where other athletes, such as Raducan, who took banned substances on the advice of their own professionals, were not.

The basis of the estoppel in Ulihrach was to prevent the organisation from applying its rules of strict liability where the detriment suffered by the athlete (the sanctions imposed following a positive test for Nandrolone) was caused by the organisation through the conduct of its trainers. As stated above, the clubs in the NRL and AFL are contractually permitted to punish players who have committed an offence of doping. Where a 'sports scientist' appointed by a club has distributed banned substances, the clubs, which bear ultimate responsibility, will, should the rationale of Ulihrach be followed, be estopped from prosecuting players who consumed those substances while ignorant of any illegality.

The further question is whether the NRL and AFL as parent bodies of their sports will also be estopped from prosecuting players for doping where clubs playing within the NRL or AFL competitions supplied players with banned substances. Returning to the broad definition of estoppel: it is essential that the plaintiff be able to show that the party to be estopped 'played such a part in the adoption of the assumption' that drove the actions of the plaintiff 'that it would be unfair or unjust if he were left free to ignore it'. ${ }^{65}$

It can be said at the outset that a parent body which is unconnected with the supply of banned substances is unlikely to be estopped by a court of law from prosecuting athletes according to a contractual right. ${ }^{66}$ Nonetheless, two possible scenarios can be proposed for purposes of argument.

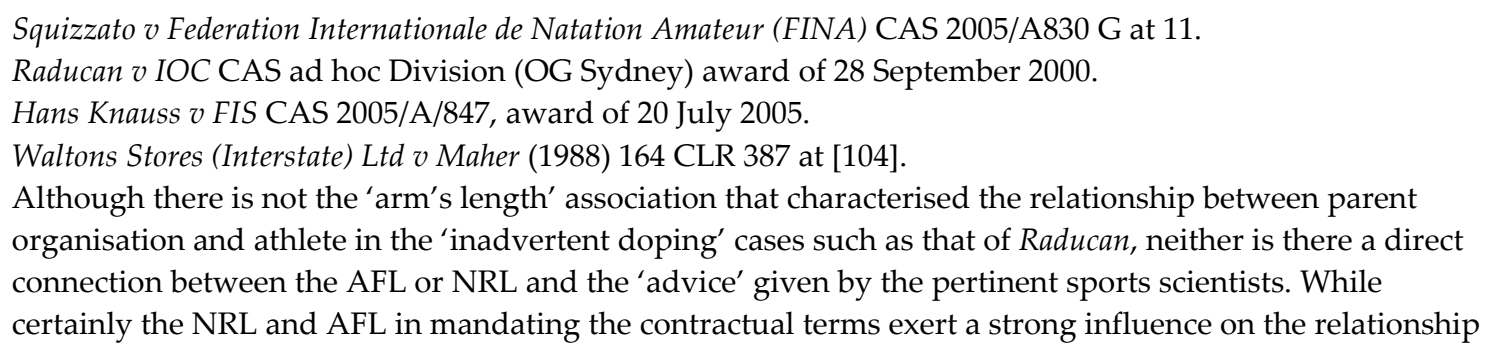


One, a parent body possessing at least some information that a 'sports scientist' may have been breaching the WADC, could be estopped from asserting its entitlement to prosecute the players concerned. Two, while the contractual arrangements and conventions that guide the state of affairs between the parent bodies and their clubs are not publically known, a club may argue that in circumstances where the club distributed banned substances, the parent organisation would be estopped from asserting its contractual right to penalise the players of that club.

As suggested earlier, a moral argument emerging from an estoppel applied to the clubs by a court of law should not be underestimated in the context of AFL and NRL: sports where marketing and sponsor concerns operate alongside an abiding public belief in good will and fair play. To dismiss these commercial and social realities out of hand is to ignore the force of public opinion and invite questions as to the governance of these sports in the eyes of non-official stakeholders.

A number of statements in Ulihrach are pertinent to this moral argument. The CAS Appeals Tribunal commented that the ATP 'is to be commended for the integrity with which it conducted itself. To the ATP's credit and with considerable courage it voluntarily undertook in the face of a very perplexing set of facts to investigate and ultimately implicate itself in the problem in which they and the players found themselves. ${ }^{67}$ The investigative report undertaken by Young for the ATP commented in similar vein that 'the Tribunal's decision in Ulihrach not only makes good legal sense, it is also the only fair outcome in that case.' ${ }^{\prime} 8$ Clearly the AFL and NRL are not directly responsible for the doping of players. The lesson lies not in the unconscionability of the parent organisation but in what is a fair outcome for a player in the AFL/NRL competitions where his club is estopped from denying its responsibility for the administration of banned substances to unsuspecting players by its employees or appointees.

There is also an arguable tactical advantage for clubs that face the prospect of a team sanction in accepting responsibility to the exclusion of the players. ${ }^{69}$ Under the AFL Anti-Doping Code:

Where more than one Player from a Club has been notified of a possible Anti Doping Rule Violation in any one season, the Club shall be subject to Target Testing for the remainder of the season. If more than one Player in a Club is found to have committed an Anti Doping Rule Violation during a season, the Club may be subject to sanctions to be determined, in their absolute discretion, by the Commission. ${ }^{70}$

Where a penalty for multiple breaches by individual team members is to be imposed, there is logic in advancing the proposition that a team sanction, which could involve the severe sanctions of removing a team from a competition or the cancellation of points, is not appropriate where the players concerned have been exonerated. Indeed, the parent body itself may, as a 'practical' remedy, welcome such an outcome. ${ }^{71}$

between player and club the relationship between the player and the organisation (see Bulldogs Rugby League Club Ltd $v$ Williams [2008] NSWSC 822, footnoted above) this alone is unlikely to be sufficient to establish an estoppel.

67 Decision of the ATP Tour Anti-Doping Tribunal on the re-opening of the hearing appeal of Bohdan Ulihrach at [30].

68 Young R, Investigative report regarding the detection of 19-norandrosterone in the urine of numerous ATP players between August 2002 and May 2003, at 10.

69 Article 11.2 of the WADC states: 'If two or more members of a team in a Team Sport are found to have committed an anti-doping rule violation during an Event Period, the ruling body of the Event shall impose an appropriate sanction on the team ...'

$70 \quad$ National Anti-Doping Code, AFL, June 2013, section 22.

71 Consider the reported response of the NRL to the possibility of team sanctions under the WADA scheme: 'The NRL has written to the World Anti-Doping Agency, arguing against proposed amendments to its code which would automatically disqualify teams for two seasons if more than one of their players failed an incompetition test. ... "The effect of the new proposed rule is that the NRL would have to disqualify (a club) from the NRL competition the following season and that Rugby League International Federation would 


\section{CONCLUSION}

A player charged with doping will claim that the club, as his employer and as the body entitled to enforce the anti-doping code against him, is estopped from utilising that code where the club's 'official' administered the banned substance. Given the example of Ulihrach and the application of estoppel in Australia, it is arguable that a player's club will be estopped from either enforcing the anti-doping code against him or in denying its responsibility for the player's assumption that substances supplied by club 'officials' conformed to the WADC. The argument is also relevant to others, such as a coach, who, on the advice of club officials, encouraged player participation in a 'supplements' scheme. A parent body which then sought to prosecute the player for doping will be in the invidious position of placing blame on a player who a court of law has ruled blame does not belong. This is not to say that the parent organisations are not contractually entitled to pursue a player under the strict liability mechanism of the anti-doping code, and in so doing impose a two year ban on that player's capacity to earn his living, merely that to do so is not without moral, public and perhaps commercial cost. ${ }^{72}$

At the very least, should a court of law determine that a club is estopped from denying responsibility for the doping of its players, there is a concrete base from which to claim 'no fault or negligence' or 'no serious fault or negligence' under the AFL and NRL Anti-Doping Codes, which could conceivably result in the elimination of a penalty or a reduction of penalty by up to one half. ${ }^{73}$

As stated above, where it is shown that players were aware of an illegality, relief cannot be expected and nor is it warranted.

have to ban (it) from all events for 12 months," the submission read. "The consequences for other members of the football club, supporters, coaches, the team itself would be catastrophic".' Garry C, 'NRL argues against WADA code changes', The Courier Mail, 11 March 2013.

72 It should be noted that any internal dispute mechanisms, including an internal appeal, will usually need to be completed prior to formal litigation (see, for example: $R v$ Williams; Ex parte Lewis [1992] 1 Qd R 643; cf. $R$ $v$ Cook; Ex parte Twigg (1980) 147 CLR 15). For example, the NRL Player Contract at section 11.2 permits a player to disciplined by his club to seek leave to appeal the NRL Appeals Committee. There is no reason why the issues of estoppel mentioned above should not form part of a case before the internal tribunal or appeals body.

73 National Anti-Doping Code, AFL, June 2013, section 14.4 (a) and (b) respectively: (a) ‘f the Player establishes in an individual case that he bears No Fault or Negligence for the violation, the otherwise applicable period of Ineligibility shall be eliminated. ...' (b) 'If a Player or other Person establishes in an individual case that he or she bears No Significant Fault or Negligence, then the otherwise applicable period of Ineligibility may be reduced, but the reduced period of Ineligibility may not be less than one-half of the minimum period of Ineligibility otherwise applicable....' 